\title{
KEABSAHAN WAKAF INTELLECTUAL PROPERTY RIGHT DALAM UNDANG- UNDANG PERWAKAFAN DI INDONESIA MENURUT HUKUM ISLAM
}

\author{
Moch. Nurcholis \\ Institut Agama Islam Bani Fattah Jombang, Indonesia \\ E-mail: cholis1986@gmail.com
}

\begin{abstract}
The discourse about waqf property in Islamic Law is closely related to the formulation of the concept of property. The discourse revolves around the question of whether the definition of the waqf object refers to its material side in the sense of 'ainul alwaqf, or does it refer to the substance side in terms of benefits and results. Can immaterial objects such as Intellectual Property Right can be used as endowments. This research is a type of qualitative research. Judging from the data collection type library research. The approach used is juridical-normative. In data analysis, the author uses content analyst methods, descriptive using a deductive mindset. The results of the study concluded that the waqf in the form of Intellectual Property Right as contained in the Indonesian Representative Law in Indonesia is valid according to Islamic Law, because it has been in accordance with the view of one of the schools of fiqh, namely the mâlikîy school, which permits waqf in the form of benefits. This conformity is produced through the method of illhâq almasâ'il bi nadairihâ (equating a problem with a comparable one). The point of conformity between the two is equally including objects that are immaterial
\end{abstract}

Keywords: Intellectual Property Right, Waqf, Islamic Law.

\section{Pendahuluan}

Lahirnya Undang-Undang Nomor 41 Tahun 2004 tentang Wakaf di Indonesia sebagai penyempurna dari peraturan perundang-undangan yang telah ada, merupakan langkah yang perlu mendapat apresiasi dari umat Islam di Indonesia. Sebab, selain sebagai penjamin kepastian hukum wakaf, Undang-Undang tersebut juga menjamin unifikasi hukum perwakafan di seluruh nusantara. Terdapat dua alasan yang mendasari dibentuknya UU Nomor 41 Tahun 2004 tentang Wakaf. Pertama, memajukan kesejahteraan umum. Untuk mencapai tujuan tersebut, 
potensi yang terdapat dalam pranata keagamaan yang memiliki manfaat ekonomis perlu digali dan dikembangkan. Dalam hal ini di antaranya adalah wakaf, yang pada awalnya berfungsi sebagai sarana ibadah dan sosial, menjadi pranata yang memiliki kekuatan ekonomi yang diyakini dapat memajukan kesejahteraan umum. Kedua, praktik yang sekarang ada pada masyarakat belum sepenuhnya berjalan tertib dan efisien. Salah satu buktinya adalah di antara harta benda wakaf tidak terpelihara dengan baik, terlantar, bahkan beralih ke tangan pihak ketiga dengan cara melawan hukum. ${ }^{1}$ Said Agil Almunawwar (mantan menteri agama, wakil dari pemerintah yang berkedudukan sebagai pengusul Undang-Undang wakaf), pernah menyatakan tujuan Undang-undang wakaf. Pertama, menjamin kepastian hukum di bidang perwakafan. Kedua, melindungi dan memberikan rasa aman bagi umat Islam sebagai wâqif. Ketiga, sebagai instrumen untuk mengembangkan rasa tanggung-jawab bagi para pihak yang mendapat kepercayaan mengelola harta wakaf. Keempat, sebagai koridor hukum untuk advokasi dan penyelesaian kasus-kasus perwakafan yang terjadi di masyarakat. ${ }^{2}$

Undang-Undang Nomor 41 Tahun 2004 tentang wakaf hadir sebagai bentuk pengembangan dan penyempurnaan terhadap materi perwakafan yang ada pada perundang-undangan sebelumnya. Bentuk pengembangan dan penyempurnaan itu misalnya berkaitan dengan obyek wakaf. Jika dalam PP. No. 28 Tahun 1977 obyek wakaf terbatas berupa tanah milik, maka dalam undang-undang wakaf yang baru ini objek wakaf dapat berupa harta bergerak yang tidak bisa habis karena konsumsi, meliputi: (a) uang (b) logam mulia (c) surat berharga (d) kendaraan (e) hak atas kekayaan intelektual (f) hak sewa (g) benda bergerak lain sesuai dengan ketentuan syariah dan peraturan perundang-undangan yang berlaku. ${ }^{3}$

Permasalahan kemudian muncul terkait keabsahan mewakafkan benda bergerak berupa Intellectual Property Right (Hak Atas Kekayaan Intelektual) menurut Hukum Islam (Fikih). Fikih secara sistematik belum mengangkat hak cipta keilmuan, seperti hak paten atas merek dagang sebagai hak milik perorangan atau kelompok yang tunduk pada hukum perlindungan. Produk ilmu pengetahuan yang dimanfaatkan seizin atau tanpa izin dari penemunya, justru tercatat sebagai akses perolehan pahala yang tetap berlanjut pasca kematian penemu ilmu tersebut. Selain itu, keberadaan Intellectual Property Right (Hak Atas Kekayaan Intelektual) yang tidak berwujud (immateri) membutuhkan sebuah upaya penalaran terkait

\footnotetext{
1 Jaih Mubarok, Wakaf Produktif, edisi ke I (Bandung: Simbiosa Rekatama Media, 2008), 57.

2 Jaih Mubarok, Wakaf Produktif, 59.

3 Pasal 1 dan 16 Undang-Undang Nomor 41 Tahun 2004 Tentang Wakaf.
} 
kelayakannya memasuki wilayah cakupan definisi harta benda wakaf yang telah ditetapkan oleh fikih.

\section{Konsepsi Umum tentang Wakaf}

Secara bahasa, wakaf berasal dari bahasa Arab al-waqf bentuk masdar dari waqafa-yaqifu-waqfan. ${ }^{4}$ Sebagai kata benda, kata al-waqf semakna dengan kata al-babs. Kalimat: habistu-abbisu-habsan dan kalimat: abbistuabbistu-abbasan maksudnya adalah waqaftu (saya menahan). ${ }^{5}$

Berpijak dari pengertian wakaf menurut bahasa di atas, dapat disimpulkan, bahwa al-habs maupun al-waqf sama-sama mengandung makna menahan, mencegah atau melarang dan diam. Dikatakan menahan, karena wakaf ditahan dari kerusakan, penjualan dan semua tindakan yang tidak sesuai dengan tujuan wakaf.

Sedangkan secara istilah para ulama mendefinisikannya secara beragam. ${ }^{6}$ Ragam definisi mengarah pada satu titik bahwa wakaf adalah upaya menyisihkan sebagian harta milik yang diperuntukkan bagi hal-hal

4 A.W. Munawwir, Kamus al-Munawnir Arab-Indonesia Terlengkap (Surabaya: Pustaka Progressif, 1997), 1576.

5 'Abd. al-Raûf ibn Tâj al-'Ârifin, Taisîr al-Wuqûf 'alâ Gawâmị al-Wuqûf (Mekah: Maktabat Nizâr Muṣtafâ al-Bâz, 1998), 15.

6 Terdapat beberapa ragam definisi tentang wakaf yang dikemukakan oleh para ulama' sebagaimana berikut:

- Imam Abû Ḥanîfah mendefinisikanan wakaf dengan:

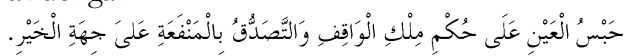

"Menahan harta di bawah tangan pemiliknya, dan menyedekabkean manfaatnya untuk jalan kebaikan". (Kamâl al-Dîn Muhammad ibn 'Abd al-Wâhịid al-Sîwâsîy al-Sakandarîy ibn Humâm, Faṭ̣ alQadîr, Vol. 6, (Beirut: Dâr al-Kutub al-'Ilmîyah, 1995), 190.)

- Mazhab Mâlikîy mendefinisakan wakaf dengan redaksi:

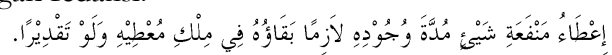

"Memberikan manfaat dari sesutu ketika sesuatu itu masih ada dengan tetapnya hak kepemilikan benda pada orang yang memberikan walaupun hanya kiasan'. (Muhammad 'Ulais, Minạ al-Jalil Syarb Mukbtasâr Khalîl, Vol. 8 (Beirut: Dâr al-Fikr, 1989), 108.)

- Menurut Mazhab Syâfîîy mendefinisakan wakaf dengan redaksi:

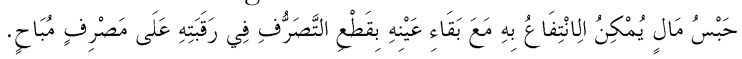

"Menahan harta yang dapat diambil manfaatnya disertai dengan kekalnya benda dengan menetapkan penggunaan benda tersebut kepada perkara yang dibolebkan oleb syarak". (Syams al-Dîn Muhammad ibn Khatîb al-Syarbînîy, Mugn al-Mubtâj, Vol. 2 (Beirut: Dâr al-Fikr, 2001), 510.)

- Sedangkan menurut Mazhab Ḥanbalîy, wakaf adalah:

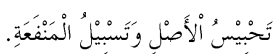

"Wakaf adalah menahan yang asal (barta yang diwakafkan) dan memberikan manfaatnya". (Syams alDîn Abî al-Faraj 'Abd al-Rahmân ibn 'Alî 'Amr Muhammad ibn Aḥmad ibn Qudâmah alMaqdisîy, al-Syarh al-Kabîr, Vol. 6 (Mekah: Maktabat Dâr al-Bâz, t.t.), 185.) 
yang bernilai positif dengan dilandasi ketulusan menjalankan ajaran agama.

Ditinjau dari segi peruntukannya, terdapat dua macam bentuk wakaf. Pertama, wakaf abliy. Wakaf abliy disebut juga wakaf keluarga atau wakaf khusus, yang dimaksud dengan wakaf ablîy ialah wakaf yang ditujukan kepada orang-orang tertentu, seseorang atau terbilang, baik keluarga wâqif maupun orang lain. ${ }^{7}$ Seperti apabila ada seseorang mewakafkan sebidang tanah kepada anaknya, lalu kepada cucunya, wakafnya sah dan yang berhak mengambil manfaatnya adalah mereka yang ditunjuk dalam pernyataan wakaf. Wakaf jenis ini, kadang-kadang juga disebut wakaf 'alâ al-aulâd, yaitu wakaf yang diperuntukkan bagi kepentingan dan jaminan sosial dalam lingkungan keluarga, lingkungan kerabat sendiri. ${ }^{8}$ Kedua, wakaf khairîy. Praktik wakaf khairy dalam kehidupan masyarakat dikenal dengan istilah wakaf sosial. Dikatakan demikian, karena wakaf ini diberikan oleh si wâqif agar manfaatnya dapat dinikmati oleh kalangan masyarakat secara umum, tidak oleh orang-orang tertentu saja. ${ }^{9}$ Seperti, mewakafkan tanah untuk mendirikan masjid, mewakafkan sebidang kebun yang hasilnya dapat dimanfaatkan untuk membina suatu pengajian dan sebagainya. ${ }^{10}$

Semua mazhab sepakat bahwa tujuan wakaf adalah untuk ibadah. ${ }^{11}$ Oleh karenanya, wakaf harus bertujuan untuk hal-hal yang baik serta berguna, tidak mengenai hal-hal yang dilarang oleh agama seperti untuk tempat perjudian, porstitusi dan tempat kemaksiatan lainnya. ${ }^{12}$ Bahkan, menurut pendapat mazhab Syâfi'îy, diperbolehkan wakaf yang dilakukan oleh penganut agama lain asalkan untuk hal-hal yang bersifat positif menurut syarak. ${ }^{13}$ Mazhab Hanafiy berpendapat bahwa wakaf yang dilakun Non-Muslim tidaklah sah, sama halnya dengan wakaf terhadap hal-hal yang dilarang oleh agama seperti wakaf untuk tempat perjudian. Sebaliknya, menurut mazhab Mâlikîy, mazhab Syâfi'îy, dan mazhab Hanbalîy perwakafan oleh orang bukan Islam yang bertujuan untuk

\footnotetext{
7 Munżir Qahâf, al-Waqf al-Islâmîy (Manajemen Wakaf Produktif), alih bahasa Muhyiddin Mas Rida (Jakarta: Khalifa, 2005), 24.

8 Sayyid Sâbiq, Fiqh al-Sunnah (Beirut: Dâr al-'Arabîy, 1997), 378.

${ }^{9}$ Qahâf, al-W aqf al-Islâmîy..., 24.

10 Direktorat Jenderal Bimas dan Penyelenggaraan Haji, Fikih Wakaf (Jakarta: Departemen Agama, 2003), 221-222.

11 Wạ̣bah al-Zuhailîy, al-Fiqh al-Islâmîy wa 'Adillatuh, Vol. 10 (Beirut: Dâr al-Fikr, 1997), 7645.

12 Muḥammad Amîn ibn 'Abidîn, Radd al-Mukhtâr 'alâ al-Durr al-Mukhtâr, Vol. 6 (Beirût: Dâr al-Fikr, 2005), 537.

13 Al-Syarbînîy, Mugn al-Mụtâj..., 515.
} 
membantu kepentingan umum adalah sah. ${ }^{14}$ Namun demikian, Para ulama fikih pada prinsipnya dalam beberapa hal mempunyai pendapat yang sama, yaitu bahwa wakaf sangat dianjurkan dalam agama Islam sebagai amal yang utama dan berguna untuk kepentingan agama. Persamaan itu khususnya dalam hal wakaf untuk masjid, wakaf yang telah diputuskan oleh hakim dan wakaf yang berbentuk wasiat (pesan menjelang ajal), serta sesuatu yang disedekahkan adalah hasil benda atau manfaatnya, bukan bendanya. Perbedaan pendapat antara para mujtabidîn tersebut di atas adalah saling mengisi satu dengan yang lain, yang diperlukan dalam menyelesaikan kasus yang berbeda.

\section{Objek Wakaf dalam Hukum Islam}

Terdapat beberapa corak pendapat di kalangan para ulama menyangkut objek yang legal untuk diwakafkan. Perbedaan pendapat ini tidak terlepas dari konsepsi masing-masing ulama menyangkut hakekat wakaf. Berikut disajikan ragama pendapat sebagaimana dimaksud.

Pertama, mazhab Hanafiy. Kriteria benda wakaf yang ditetapkan oleh mazhab ini adalah sesuatu yang tidak dapat dipindah dan dirubah, seperti 'aqâr dan yang semisalnya, maka tidak diperbolehkan mewakafkan manqûl, dan harta yang bisa dibagi (bukan milik bersama yang tidak bisa dibagi). ${ }^{15}$ 'Aqâr yang dimaksud di sini, sebagaimana dijelaskan oleh Wahbah adalah sesuatu yang tidak dapat dipindah dan dirubah dari satu tempat ketempat yang lain, seperti rumah dan tanah. ${ }^{16}$ Lebih lanjut Waḥbah menjelaskan pengertian manqûl menurut mazhab Hanafìy dengan mengatakan:

"Manqûl adalah sesuatu yang bisa dipindah dan dirubah dari satu tempat ke tempat yang lain, baik tetap dalam bentuk dan keadaan semula, atau terjadi perubahan pada bentuk dan keadaannya sebab proses perpindahan dan perubahan.

Termasuk di dalamnya mata uang, harta perdagangan, berbagai jenis hewan, benda-

benda yang dapat ditakar dan ditimbang". ${ }^{17}$

Dengan menetapakan dua syarat ini, dalam mazhab Hanafiy mewakafkan benda-benda bergerak seperti mobil, hewan ternak dan lainnya tidak diperbolehkan. ${ }^{18}$ Secara umum mazhab Hanafîy hanya memperbolehkan wakaf 'aqâr (tanah dan sejenisnya) saja. Adapun benda-

\footnotetext{
14 Al-Syarbînîy, Mugn al-Mubtajj..., 7601.

15 Alâ’ al-Dîn Abû Bakr ibn Mas 'ûd al-Kâsânîy al-Ḥanafîy, Badâ'i' al-Sanâ'i', Vol. 6 (Beirut:

Dâr al-Ma'rifah, 2000), 349.

16 Al-Zuhailîy, al-Fiqh al-Islâmîy..., 2881.

17 Al-Zuhailîy, al-Figh al-Islâmîy..., 2881.

18 Ibn Humâm, Faț al-Qadîr..., 200.
} 
benda bergerak (al-manqûh) yang boleh diwakafkan hanyalah bersifat pengecualian dari aturan umum. Mazhab Hanafiy telah menetapkan cara pelestarian keabadian benda wakaf dengan mengganti benda tersebut. Sehingga apabila berlaku kebiasaan wakaf uang dinar (emas) dan dirham (perak) yang mana keduanya tidak mungkin diambil manfaatnya dengan tetapnya keadaan, maka nilai dari mata uang tersebut dirupakan atau dibelikan tanah agar kemanfaatan benda wakaf tetap terjaga. ${ }^{19}$

Kedua, mazhab Mâlikîy. Mazhab Mâlikîy menetapkan kriteria benda wakaf adalah sesuatu yang bisa dimiliki (al-mamlûk). ${ }^{20}$ Ulama mazhab Mâlikîy menjelaskan tentang hakekat benda yang dapat dimiliki adalah "Sesuatu yang mencakup kepemilikan atas żat dan kepemilikan atas manfaat". ${ }^{21}$ Lebih lanjut juga dijelaskan bahwa al-mamluke adalah:

"Sesuatu yang dapat dimiliki żatnya walaupun sesuatu tersebut tidak boleh diperjualbelikan, seperti kulit hewan kurban, anjing pemburu, dan semisalnya. Sab mewakafkan hamba yang hilang. Termasuk dalam kategori benda yang dapat dimiliki adalah al-'aqâr (benda tak bergerak), al-muqawwâm (benda bermanfaat secara syara'), al-mislîy (benda yang memiliki padanan) dan binatang”."22

Dari uraian di atas, dapat disimpulkan bahwa mazhab Mâlikîy memperbolehkan beberapa jenis benda wakaf. Pertama, aqâr (benda tak bergerak) dan al-manqûl (benda yang dapat dipindah). Kedua, drat (benda materiil) dan manfaat (benda immateriil). Ketiga, musyâ' (harta milik bersama) dengan syarat apabila benda tersebut masih dimungkinkan untuk dibagi. Secara umum, menurut mazhab Mâlikîy semua yang dapat dimiliki, baik itu berupa benda, baik tidak bergerak ataupun benda bergerak, atau berupa manfaat dari suatu benda boleh untuk diwakafkan.

Ketiga, mazhab Syâfi'îy. Mazhab Syâfi'îy menerapkan kriteria yang cukup ketat dalam benda wakaf dengan menyatakan:

"Syarat benda wakaf adalab harus berupa benda tertentu yang dapat dimiliki dengan kepemilikan yang dapat dipindabkan, dapat diambil faedah atau manfaat dengan tetapnya keadaan benda tersebut, sab untuk disewakan dan dapat dimanfaatkan dalam jangka waktu yang lama".23

Dari kriteria tersebut di atas dapat disimpulkan bahwa objek wakaf menurut mazhab Syâfi'îy harus memenuhi beberapa persyaratan. Pertama,

\footnotetext{
19 Al-Zuhailîy, al-Figh al-Islâmîy..., 7610.

20 'Ulais, Minạ al-Jalîl..., 109.

21 Abu al-Barakât Aḥmad ibn Muhammad al-'Adawîy, al-Syarh al-Kabîr, dicetak bersama Al-

Dasûqîy, Hâsyizat al-Dasûqûy, Vol. 5 (Beirut: Dâr al-Kutub al-'Ilmîyah, 1996), 455.

22 Abu al-Barakât, al-Syarb al-Kabîr, 455.

${ }^{23}$ Syams al-Dîn Muḥammad ibn Abi al-Abbâs Ạ̣mad ibn Hamzah ibn Syihâb al-Dîn alRamlîy, Nihâyat al-Mubtâj, Vol. 5 (Beirut: Dâr al-Fikr, tt), 360-361.
} 
harus berupa benda, maka tidak sah wakaf manfaat. ${ }^{24}$ Kedua, benda tersebut bisa dimiliki, karenanya seorang yang merdeka tidak boleh mewakafkan dirinya. ${ }^{25}$ Ketiga, dapat dimiliki dengan kepemilikan yang dapat dialihkan, maka tidak sah mewakafkan 'umm al-walad dan bayi dalam kandungan. ${ }^{26}$ Keempat, dapat dimanfaatkan dalam jangka waktu yang lama, maka tidak sah mewakafkan makanan dan wangi-wangian. ${ }^{27}$ Mazhab Syâfi'îy memperbolehkan wakaf 'aqâr (benda tak bergerak seperti tanah dan bangunan) al-manqûl (benda bergerak seperti pakaian dan kitab) dan al-musyâ' (harta bersama), baik berupa 'aqâr maupun manqû̉).

Keempat, mazhab Hanbalîy. Mazhab Hanbalîy menetapkan kriteria sebuah benda dapat menjadi objek wakaf dengan menyatakan bahwa benda wakaf adalah Benda yang boleh diperjualbelikan, dapat dimanfaatkan dalam jangka waktu yang lama dengan tetapnya keadaan benda tersebut, seperti hewan, 'aqâr (benda tak bergerak) dan pedang. ${ }^{29}$ Menurut mazhab Hanbalîy kriteria benda wakaf harus memenuhi dua kriteria. Pertama, benda yang sah untuk diperjual belikan. Oleh karenaya, tidak sah mewakafkan anjing, babi, barang yang digadaikan serta hal-hal lain yang tidak sah unutuk diperjualbelikan. Kedua, benda yang dapat dimanfaatkan dalam jangka waktu yang lama dengan tetapnya keadaan benda tersebut, karenanya tidak sah mewakafkan sesatu yang tidak bisa dimanfaatkan dalam jangka waktu yang lama seperti makanan dan wangiwangian. Sebagaimana mazhab Syâfi'îy, mazhab Hanbalîy juga memperbolehkan wakaf 'aqâr (benda tak bergerak) al-manqûl (benda bergerak) dan al-musyâ' (harta bersama, baik berupa 'aqâr maupun almanqû̉..$^{30}$

Dari seluruh paparan pendapat ulama fikih di atas, diketahui bahwa jenis benda-benda yang dapat dijadikan sebagai benda wakaf. Pertama, 'aqâr (benda tak bergerak). Ulama sepakat atas kebolehan wakaf 'aqâr seperti, kebun, pekarangan, rumah dan semisalnya). ${ }^{31}$ Kedua, manqûl (benda yang bisa dipindah). Dalam wakaf manqûl, hanya ulama Hanafiyah

\footnotetext{
24 Al-Ramlîy, Nihâyat al-Mubtâj, 360.

25 Abû Ishâq Ibrâhịim ibn 'Alî ibn Yûsuf al-Fairûz Abâdî al-Syîrâzîy, al-Muhaż̃ab, Vol. 1

(Beirut: Dâr al-Fikr, 1994), 117.

26 Al-Syîrâzîy, al-Mubazzab, 619.

27 Al-Syarbînîy, Mugn al-Mubtâj..., 512.

28 'Abd. al-Ra' ûf, Taisîr..., 41.

29 Al-Maqdisîy, al-Syarh al-Kabîr..., 188.

30 Al-Maqdisîy, al-Syarh al-Kabîr..., 187.

31 Al-Zuhailîy, al-Fiqh al-Islamîy..., 7609.
} 
saja yang tidak memperbolehkan. Meskipun ada beberapa jenis manqûl yang diperbolehkan, akan tetapi hal itu hanya pengecualian dari ketentuan umum. ${ }^{32}$ Ketiga, musyâ' (harta bersama). Untuk musyâ' yang dapat dibagi, ulama sepakat atas kebolehannya. Sedangkan untuk musya yang tidak bisa dibagi, maka ulama berbeda pendapat. Bagi ulama yang mensyaratkan benda wakaf harus bisa diserah terimakan, maka wakaf musyâ tidak diperbolehkan. Sedangkan bagi ulama yang tidak mensyaratkannya, maka wakaf musyâ' berhukum boleh. ${ }^{33}$

\section{Objek Wakaf dalam Undang-Undang Perwakafan di Indonesia}

Di Indonesi perwakafan di atur dalam Undang-undang Nomor 41 Tahun 2004 tentang Wakaf. Undang-Undang ini, disamping untuk menjamin legalitas wakaf di Indonesia juga memiliki semangat pemberdayaan wakaf secara produktif-profesional. Hal ini setidaknya terbaca dari definisi wakaf yang terdapat dalam pada Pasal 1 ayat (1) UU Nomor 41 Tahun 2004;

Wakaf adalab perbuatan bukum wakif untuk memisabkan dan/atau menyerabkan sebagian harta benda miliknya untuk dimanfaatkan selamanya atau untuk. jangka waktu tertentu sesuai dengan kepentingan guna keperluan ibadah dan/atau kesejabteraan umum menurut syariah. ${ }^{34}$

Jika dalam definisi ulama fikih, wakaf lebih lekat dengan nuansa ibadah sakral, todak demikian halnya dengan definisi wakaf dalam undang-undang yang juga mengakomodir nuansa ibadah profan. Kesejahteraan umum ditetapkan sebagai ujung yang harus terwujud dari adanya pranata wakaf.

Lebih dari itu, undang-undang perwakafan di Indonesia telah berusaha melanjutkan visi dari aturan wakaf dalam fikih, khususnya menyangkut objek wakaf. Jika dalam fikih objek wakaf lebih didominasi oleh benda-benda yang mempunyai materi ("ain), undang-undang perwakafan di Indonesia telah melakukan perluasan yang terhadap kriteria objek wakaf. Pasal 1 ayat (5) UU No. 41 Tahun 2004 tentang wakaf menyatakan bahwa harta benda wakaf adalah harta benda yang memiliki daya tahan lama dan/atau manfaat jangka panjang serta mempunyai nilai ekonomi menurut syariah yang diwakafkan oleh wâqif. ${ }^{35}$ Lebih lanjut dipertegas dalam Pasal 16 ayat (1) bahwa harta benda wakaf terdiri dari: (a) benda tidak bergerak (b) benda bergerak. Ayat (3) benda

\footnotetext{
32 Al-Zuhailîy, al-Figh al-Islâmîy..., 7610.

33 Al-Zuhailîy, al-Figh al-Islâmîy..., 7611.

34 Pasal 1 ayat (1) Undang-Undang Nomor 41 Tahun 2004 Tentang Wakaf.

35 Pasal 1 ayat (5) Undang-Undang Nomor 41 Tahun 2004 Tentang Wakaf.
} 
bergerak yang sebagaimana dimaksud pada ayat (1) huruf $\mathrm{b}$ adalah benda yang tidak bisa habis karena konsumsi, meliputi: (a) uang (b) logam mulia (c) surat berharga (d) kendaraan (e) hak atas kekayaan intelektual (f) hak sewa (g) benda bergerak lain sesuai dengan ketentuan syariah dan peraturan perundang-undangan yang berlaku. ${ }^{36}$ Dalam undang-undang ini, juga diatur adanya wakaf benda bergerak, seperti uang, saham, suratsurat berharga lainnya dan Intellectual Property Right (Hak Atas Kekayaan Intelektual). Tentu saja ini merupakan terobosan yang cukup signifikan dalam dunia perwakafan, karena wakaf seperti uang, saham dan surat berharga lainnya dan Intellectual Property Right, merupakan bagian penting dalam pengembangan ekonomi.

Intellectual Property Right atau Hak Atas Kekayaan Intelektual adalah Hak untuk menikmati secara ekonomis dari suatu kreativitas intelektual yang menghasilkan suatu produk atau proses yang berguna untuk manusia, baik di bidang teknologi, ilmu pengetahuan, seni dan sastra. Tegasnya, Intellectual Property Right adalah hak milik yang dapat dikomersialkan untuk memperoleh uang atau kekayaan kebendaan. ${ }^{37}$ Secara Rinci, Intellectual Property Right terbagi menjadi 7 (tujuh) macam, meliputi hak cipta, paten, merek (merek jasa, merek kolektif, merek dagang), desain industry, desain tata letak sirkuit terpadu, rahasia dagang, varietas tanaman. ${ }^{38}$

\section{Analisis}

Di Indonesia, cakupan obyek wakaf semakin meluas setelah keluarnya Undang-Undang Nomor 41 Tahun 2004 tentang Wakaf kemudian disusul dengan PP Nomor 42 Tahun 2006 tentang Pelaksanaan UndangUndang Nomor 41 Tahun 2004 tentang Wakaf. Dalam PP tersebut disebutkan bahwa jenis harta benda wakaf meliputi benda tidak bergerak, benda bergerak selain uang, dan benda bergerak berupa uang. Intellectual Property Right atau Hak Atas Kekayaan Intelektual termasuk dalam kategori benda bergerak selain uang. Pengkategorian ini didasarkan pada ketentuan dari undang-undang, bukan karena sifat benda tersebut. Intellectual Property Right memang termasuk sesuatu yang baru yang belum ada pada masa ulama fikih. Meskipun pembahasan tentang boleh atau tidaknya mewakafkan benda-benda immaterial yang berupa hak dan manfaat sudah diperbincangkan dalam karya mereka.

\footnotetext{
36 Pasal 16 ayat (1) Undang-Undang Nomor 41 Tahun 2004 Tentang Wakaf.

37 Agus Sarjono, Hak Kekayaan Intelektual dan Pengetahuan Tradisional (Bandung: Alumni, 2006), 125.

38 Agus Sarjono, Hak Kekayaan Intelektual, 125.
} 
Para ulama mazhab fikih memandang bahwa objek wakaf haruslah memenuhi kriteria berupa benda materiil, memiliki nilai manfaat, dan dapat bertahan dalam jangka waktu yang lama. Kriteria obyek wakaf seperti ini disampaikan oleh ulama mazhab Syâfi'îy dan Hanbalîy, keduanya tidak membatasi apakah benda tersebut berupa benda tidak bergerak seperti tanah, rumah, gedung dan lain sebagainya ataupun benda bergerak, seperti mobil, hewan ternak, buku, dan semisalnya. Hal ini berbeda dengan mazhab Hanafiy, mereka mensyaratkan obyek wakaf harus berupa benda tidak bergerak. Para ulama dari tiga mazhab berargumen bahwa wakaf harus selamanya, karenanya obyek wakaf juga harus memiliki kriteria yang ketat sehingga maksud dari wakaf yang digunakan untuk selamanya atau minimal dalam jangka waktu yang cukup lama dapat terealisasikan. Mayoritas mazhab fikih mensyaratkan obyek wakaf harus berupa benda materiil. Bahkan mazhab Hanafiy mengharuskan objek wakaf berupa benda tidak bergerak. Hal ini berbeda dengan pendapat mazhab Syâfi'îy dan mazhab Hanbalîy yang memperbolehkan objek wakaf baik berupa benda bergerak, ataupun benda tidak bergerak.

Mazhab Mâlikîy berbeda dengan tiga mazhab lainnya. Letak perbedaan tersebut setidaknya terangkum dalam tiga hal. Pertama, wakaf tidak harus selamanya, melainkan boleh dibatasi dengan jangka waktu tertentu. Kedua, objek wakaf tidak harus berupa benda materiil (berwujud). Akan tetapi juga bisa berupa benda immaterial (tidak berwujud). Ketiga, hak kepemilikan wâqif terhadap objek wakaf tidak hilang. Sebab, yang diwakafkan hanyalah manfaat dari objek wakaf dan bukan objek wakafnya.

Mazhab Mâlikîy tidak mengharuskan obyek wakaf berupa benda materiil (berwujud), akan tetapi juga dapat berupa benda immaterial (tidak berwujud). Sebagai contoh kasus, ulama Mâlikîy memperbolehkan apabila ada penyewa mewakafkan manfaat dari benda yang disewa sampai dengan batas waktu habisnya masa sewa. Dari sini terlihat bahwa yang diwakafkan bukanlah berupa benda yang bersifat materiil, akan tetapi manfaat dari benda tersebut yang bersifat immaterial. Dengan demikian, pandangan mazhab Mâlikîy terhadap objek wakaf lebih mengacu pada sisi substansinya, yakni manfaat dari benda yang diwakafkan tersebut, dan tidak hanya mengacu pada sifat kebendaannya. Hal ini kiranya dapat disamakan dengan wakaf berupa Intellectual Property Right, dimana yang diwakafkan adalah manfaat (nilai ekonomi) yang ada pada hak tersebut. 


\section{Kesimpulan}

Dari seluruh uraian yang telah dipaparkan, didapati bahwa wakaf berupa hak tidak bertentangan dengan pandangan Hukum Islam (fikih), sebab telah bersesuaian dengan pandangan salah satu mazhab fikih, yakni mazhab Mâlikîy, yang memperbolehkan wakaf berupa manfaat. Titik kesesuain diantara keduanya adalah sama-sama termasuk benda yang tidak berwujud (immaterial). Dengan menggunakan metode ill. âq al-masâ'il bi nadairibâ (penyamaan sebuah masalah dengan yang sebanding), disimpulkan bahwa hukum wakaf berupa Intellectual Property Right (Hak Atas Kekayaan Intelektual) sebagaimana terdapat dalam Undang-Undang Perwakafan Di Indonesia adalah sah menurut Hukum Islam.

\section{Daftar Pustaka}

'Adawîy (al), Abu al-Barakât Aḥmad ibn Mụhammad. Al-Syaṛ al-Kabîr. Beirut: Dâr al-Kutub al-'Ilmîyah. 1996.

'Ulais, Muhammad. Minạ̣ al-Jalîl Syarh Mukhtasâr Khalîl. Beirut: Dâr alFikr, 1989

Amîn, Muhammad Ibn 'Abidîn. Radd al-Mukbtâr 'alâ al-Durr al-Mukhtâr. Vol. 6. Beirut: Dâr al-Fikr. 2005.

Direktorat Jenderal Bimas dan Penyelenggaraan Haji. Fikih Wakaf, Jakarta: Departemen Agama. 2003.

Humâm, Ibn. Faṭh al-Qadîr.Vol. 6. Beirut: Dâr al-Kutub al-'Ilmîyah. 1995.

Kâsânîy (al), 'Alâ' al-Dîn Abû Bakr ibn Mas'ûd al-Ḥanafîy. Badâ'i' alSanâ' $i$ '. Beirut: Dâr al-Ma'rifah. 2000.

Mubarok, Jaih. Wakaf Produktif. Bandung: Simbiosa Rekatama Media. 2008.

Munawwir, A.W. Kamus al-Munawwir Arab-Indonesia Terlengkap. Surabaya: Pustaka Progressif. 1997.

Qahâf, Munżir. Al-Waqf al-Islâmîy (Manajemen Wakaf Produktif), alih bahasa Muhyiddin Mas Rida. Jakarta: Khalifa. 2005.

Qudâmah, Ibn. Al-Syaṛ al-Kabîr. Vol. 6. Mekah: Maktabat Dâr al-Bâz. t.t. Ra'ûf (al), 'Abd. Taisîr al-Wuqûf 'alâ Gawâmid al-Wuqûf. Mekah: Maktabat Nizâr Mustafâ al-Bâz. 1998.

Ramlîy (al), Syams al-Dîn Muhammad ibn 'Abi al-'Abbâs 'Aḥmad ibn Hamzah ibn Syihâb al-Dîn. Nihâyat al-Mubtâj. Vol. 5. Beirut: Dâr al-Fikr, t.t.

Sâbiq, Sayyid. Fiqh al-Sunnah. Beirut: Dâr al-'Arabîy. 1997.

Sarjono, Agus. Hak Kekayaan Intelektual dan Pengetahuan Tradisional. Bandung: Alumni. 2006. 
Syarbînîy (al), Syams al-Dîn Muhammad. Mugn al-Mụtâj. Vol. 2. Beirut: Dâr al-Fikr. 2001.

Syîrâzîy (al), 'Abû 'Ishâq 'Ibrâhîm ibn 'Alî ibn Yûsuf al-Fairûz 'Abâdî. Al-Mubazzab. Vol. 1. Beirut: Dâr al-Fikr. 1994.

Undang-Undang Nomor 41 Tahun 2004 Tentang Wakaf.

Zuhailîy (al), Wahbah. Al-Fiqh al-Islâmîy wa 'Adillatuh. Vol. 10. Beirut: Dâr al-Fikr. 1997. 